\title{
Real-time RT-PCR for H5N1 avian influenza A virus detection
}

\author{
Correspondence \\ Weijun Chen \\ chenwj@genomics.org.cn \\ Jian Wang \\ wangjian@genomics.org.cn
}

Received 20 October 2006

Accepted 11 January 2007

\author{
Weijun Chen, ${ }^{1} \dagger$ Bo He, ${ }^{1} \dagger$ Changgui $\mathrm{Li}{ }^{2} \dagger$ Xiaowei Zhang, ${ }^{1}$ Weili Wu, ${ }^{1}$ \\ Xuyang Yin, ${ }^{3}$ Baoxing Fan, ${ }^{4}$ Xingliang Fan ${ }^{2}$ and Jian Wang ${ }^{1}$ \\ ${ }^{1}$ Beijing Genomics Institute, Chinese Academy of Sciences, Beijing, China \\ ${ }^{2}$ National Institute for the Control of Pharmaceutical and Biological Products, Beijing, China \\ ${ }^{3}$ Wenzhou Medical College, Wenzhou, China \\ ${ }^{4}$ Beijing 301 Hospital, Beijing, China
}

\section{INTRODUCTION}

The highly pathogenic avian influenza virus (HPAIV) H5N1 was first isolated from humans during the 1997 outbreak in Hong Kong. Eighteen patients were confirmed to have been infected with $\mathrm{H} 5 \mathrm{~N} 1$ after close contact with poultry and six patients died (CDC, 1997). The recent recurrence of influenza A $\mathrm{H} 5 \mathrm{~N} 1$, which was first reported in Southeast Asia in mid-December 2003, is severe and has involved increasing numbers of countries. It had infected 218 people and caused 124 deaths in ten countries by May 2006 (WHO, 2006). HPAIV has not only posed a continuing global human public health risk, but also endangered the poultry industry (CDC, 2004; FAO, 2005; Tran et al., 2004; Viseshakul et al., 2004). The recurrence of influenza A H5N1 has highlighted the need for a highly

†These authors contributed equally to this paper.

Abbreviations: $E D_{50}, 50 \%$ egg infective dose; FAM, 6-carboxyfluorescein; HA, haemagglutinin; HPAIV, highly pathogenic avian influenza virus; RRT-PCR, real-time RT-PCR; TAMRA, 6-carboxytetramethylrhodamine; WHO, World Health Organization. sensitive, accurate and rapid diagnostic test for the infection. Such a test is important, not only for infection control, but also to facilitate early antiviral therapy. However, cell culture and subsequent haemagglutinin (HA) and neuraminidase subtyping by serological testing require 1-2 weeks for results; thus they are less useful in making therapeutic and infection-control decisions. On the other hand, commercially available rapid antigen tests for influenza A are rapid and simple, but subtyping ( $\mathrm{H} 1$ and H5) of viruses shows cross-reactivity (WHO, 2005). Molecular diagnosis of influenza A H5 by real-time RTPCR (RRT-PCR) can be a rapid assay: results, including subtyping, may be available in less than 1 day.

Standard RT-PCR has been applied previously to the detection of AIV and each of the 15 HA subtypes (Lee et al., 2001; Munch et al., 2001; Starick et al., 2000). The World Health Organization (WHO) has also recommended a pair of primers for $\mathrm{H} 5$ subtype detection as a laboratory test (WHO, 2005). RRT-PCR with hydrolysis probes has been applied successfully to the detection of various RNA viruses (Chen et al., 2004; Holland et al., 1991; Livak et al., 1995). 
RRT-PCR offers the advantages of speed, viral load analysis, sensitivity and specificity compared with standard RT-PCR. In this study, we developed a rapid, highly sensitive and specific real-time, fluorescent, quantitative RT-PCR for direct detection of influenza A H5.

\section{METHODS}

Samples. Throat swab samples were collected from 35 birds presenting with abnormal neurological signs and diarrhoea in Qinghai Lake, China, during the HPAIV (H5N1) outbreak in 2005 (Liu et al., 2005). Throat swab samples were also collected from 60 patients who were confirmed to be infected with influenza A H1 by RT-PCR assay (Wright et al., 1995) at Beijing 301 Hospital, China. The swabs were kept at $4{ }^{\circ} \mathrm{C}$ and transported to the laboratory within $48 \mathrm{~h}$ in PBS at $4{ }^{\circ} \mathrm{C}$ supplemented with $200 \mathrm{mg}$ streptomycin $\mathrm{ml}^{-1}$, $100 \mathrm{U}$ penicillin $\mathrm{ml}^{-1}$ and $10 \mu \mathrm{g}$ amphotericin $\mathrm{B} \mathrm{ml}^{-1}$. On receipt of the specimen, prior to any manipulation of the specimen, some aliquots were removed in a type II biological safety cabinet for molecular analysis and virus isolation.

Viruses. Sixty isolates of AIV/H5N1 that originated from different species from 1997 to 2005 were provided by the HPAIV study team. The genomes of these isolates were sequenced and they divided into different clades (Table 1 and unpublished data). The other 14 viruses were kindly provided by China Agriculture University, the Academy of Military Medicine Science and the National Institute for the Control of Pharmaceutical and Biological Products: influenza virus A/ $\mathrm{PR} / 8 / 34$ (H1N1); influenza virus A/Beijing/30/95 (H3N2); influenza virus A/duck/Taiwan/4201/99 (H7N7); influenza virus A/Swine/ Shandong/nb/2003 (H9N2); influenza virus B (Hongkong/5/72); parainfluenza viruses 1,2 and 3 ; severe acute respiratory syndromeassociated coronavirus (TJF); respiratory syncytial virus; human immunodeficiency virus 1; cytomegalovirus; Epstein-Barr virus; and adenovirus type 2 . The titres of all influenza viruses were determined by $50 \%$ egg infective dose $\left(\operatorname{EID}_{50}\right)$, whilst the titres of the other viruses were determined by quantitative PCR (Chen et al., 2004; Kubar et al., 2005; Kuypers et al., 2006; Palmer et al., 2003; Perkins et al., 2005); they were determined to be approximately $10^{4} \mathrm{EID}_{50} \mathrm{ml}^{-1}$ or $10^{6}$ copies $\mathrm{ml}^{-1}$, respectively.

Primers and probe. In view of the divergence of the $\mathrm{H} 5$ gene, we aligned all $\mathrm{H} 5$ gene sequences in the NCBI GenBank database

Table 1. Species of origin and clades of $60 \mathrm{H} 5 \mathrm{~N} 1$ isolates

\begin{tabular}{|c|c|c|c|c|c|}
\hline \multirow[t]{2}{*}{ Species } & \multicolumn{4}{|c|}{ Clade } & \multirow[t]{2}{*}{ Total } \\
\hline & 1 & 2 & 3 & Others & \\
\hline Chicken & & 5 & 17 & 16 & 38 \\
\hline Duck & 1 & 2 & 2 & 2 & 7 \\
\hline Goose & & & 2 & 1 & 3 \\
\hline White swan & & 1 & & & 1 \\
\hline Mallard & & 1 & & & 1 \\
\hline Black-headed goose & & 2 & & & 2 \\
\hline $\begin{array}{l}\text { Great black-headed } \\
\text { gull }\end{array}$ & & 1 & & & 1 \\
\hline Black-headed gull & & 1 & & & 1 \\
\hline Human & & & 2 & & 2 \\
\hline Swine & & 2 & 1 & 1 & 4 \\
\hline Total & 1 & 15 & 24 & 20 & 60 \\
\hline
\end{tabular}

$(n=252)$ and our unpublished H5N1 genome sequences $(n=60)$ and chose a conservative region from which to design the primers and probe using PRIMER EXPRESS software v2.0 (Table 2). Another H5 subtype primer set was synthesized according to data published by WHO (WHO, 2005). The probe was labelled at the $5^{\prime}$ end with 6carboxyfluorescein (FAM) reporter dye and at the $3^{\prime}$ end with 6carboxytetramethylrhodamine (TAMRA) quencher dye. All primers and the probe were synthesized by Shanghai Sangon Company.

Transcription of AIV H5 RNA in vitro. We designed a pair of universal primers to amplify the complete HA gene (forward: $5^{\prime}$ TATTGGTCTCAGGGAGCGAAAGCAGGGG-3'; reverse: 5' ${ }^{\prime}$-ATATGGTCTCGTATTAGTAGAAACAAGGGTGTTTT- $3^{\prime}$ ). The influenza A virus [A/Swine/Anhui/cb/2004 (H5N1)] H5 gene was amplified by RT-PCR and the product was cloned into the pGEM-T Easy vector (Promega). The recombinant plasmid was linearized with PstI, purified with a PCR purification kit (Shanghai Biotech) and transcribed with T7 RNA polymerase using a RiboMax Express large-scale RNA production system (Promega). The template DNA was degraded with $5 \mathrm{U}$ RNase-free DNase I and the RNA transcripts were purified twice with an RNeasy kit (Qiagen). The RNA was quantified spectrophotometrically at $260 \mathrm{~nm}$, divided into aliquots and stored at $-80^{\circ} \mathrm{C}$. Diluted AIV H5 transcripts $\left(4 \times 10^{8}-4 \times 10^{-2}\right.$ copies $\mu \mathrm{l}^{-1}$ at tenfold dilutions; $4 \times 10^{1}-7.8 \times 10^{-2}$ copies $\mu \mathrm{l}^{-1}$ at twofold dilutions) were used for the determination of detection limits and the amplification efficiency of the assay.

Standard influenza virus A/H5N1 panel. The standard avian influenza A virus/H5N1 panel was supplied by the Influenza virus A/ H5N1 Quality Assurance Laboratory, National Institute for the Control of Pharmaceutical and Biological Products. It contained eight volumes of different isolates of influenza virus A/H5N1: Hong Kong/ 213/03 (clade 1), black-headed Goose/QH/1/05 (clade 2), Anhui/1/ 2005 (clade 2) and Hong Kong/156/97 (clade 3) (two volumes of each). The concentration of each volume was approximately $10^{4}$ $\mathrm{EID}_{50} \mathrm{ml}^{-1}$.

RNA extraction. Total RNA was extracted using a QIAamp RNA extraction kit (Qiagen) according to the manufacturer's instructions. Briefly, $140 \mu \mathrm{l}$ of each sample was used for the extraction of viral genomic RNA. The RNA was eluted from the columns with $50 \mu \mathrm{l}$ DEPC-treated water and used in the following experiments immediately or stored at $-80{ }^{\circ} \mathrm{C}$. All of the above methods were performed in a Biosafety level 3 facility.

DNA extraction. DNA was extracted using a QIAamp DNA mini kit (Qiagen) according to the manufacturer's instructions. Briefly, $100 \mu \mathrm{l}$ of each virus culture was used for the extraction of viral genomic

Table 2. PCR primers and probe used for AIV H5 subtype detection

\begin{tabular}{|llc|}
\hline Primer/probe & \multicolumn{1}{c|}{ Primer sequences $\left(\mathbf{5}^{\prime} \rightarrow \mathbf{3}^{\prime}\right)$} & $\begin{array}{c}\text { PCR } \\
\text { product }(\mathbf{b p})\end{array}$ \\
\hline H5f-53* & ACATGCCCAAGACATACTGGAA & 130 \\
H5r-182 & GAATTCGTCACACATTGGGTTTC \\
H5 Probe-79 & FAM-CACACAACGGGAAGCTCT- \\
& GCGATCT-TAMRA \\
WHOf-839 & GCCATTCCACAACATACACCC & 219 \\
WHOr-1057 & CTCCCCTGCTCATTGCTATG & \\
&
\end{tabular}

${ }^{\star}$ Reference strain: influenza A virus [A/great black-headed gull/ Qinghai/1/2005 (H5N1)]. 
DNA. The DNA was eluted from the columns with $50 \mu$ l doubledistilled water. DNA was used in the following experiments immediately or stored at $-80{ }^{\circ} \mathrm{C}$.

Conventional RT-PCR. The Qiagen one-step RT-PCR kit was used for RT-PCR with a $30 \mu \mathrm{l}$ reaction mixture containing $10 \mu \mathrm{l}$ RNA, $6 \mu \mathrm{l}$ $5 \times$ buffer, $1.2 \mu \mathrm{l}$ dNTP mix $(25 \mathrm{mM}), 1.2 \mu$ enzyme mix $(25 \times)$,

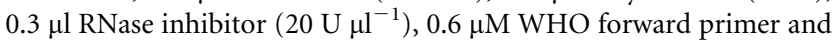
$0.6 \mu \mathrm{M}$ WHO reverse primer. The reverse transcriptase step was carried out at $50{ }^{\circ} \mathrm{C}$ for $30 \mathrm{~min}$ and $95{ }^{\circ} \mathrm{C}$ for $15 \mathrm{~min}$, followed by 40 cycles of amplification $\left(94{ }^{\circ} \mathrm{C}\right.$ for $30 \mathrm{~s} ; 55^{\circ} \mathrm{C}$ for $30 \mathrm{~s} ; 72{ }^{\circ} \mathrm{C}$ for $30 \mathrm{~s}$ ). Amplified products were detected by agarose gel electrophoresis and sequence identification. Sequencing was carried out using an ABI PRISM 3730 DNA sequencer.

RRT-PCR. RRT-PCR was carried out in a $30 \mu$ mixture containing $10 \mu \mathrm{l}$ RNA, $15 \mu \mathrm{l} 2 \times$ Taqman one-step RT-PCR master mix (ABI), $0.75 \mu \mathrm{l} 40 \times$ MultiScribe and RNase inhibitor mixture, $0.25 \mu \mathrm{M}$ forward primer, $0.25 \mu \mathrm{M}$ reverse primer and $0.125 \mu \mathrm{M}$ probe in a fluorometric PCR thermocycler (ABI 7300). The reaction was carried out for $30 \mathrm{~min}$ at $48{ }^{\circ} \mathrm{C}$, followed by $10 \mathrm{~min}$ at $95{ }^{\circ} \mathrm{C}$, with a subsequent 40 cycles of amplification $\left(95^{\circ} \mathrm{C}\right.$ for $15 \mathrm{~s} ; 60^{\circ} \mathrm{C}$ for $1 \mathrm{~min}$; fluorescence was recorded at $60{ }^{\circ} \mathrm{C}$ ).

Antigen-capture ELISA. All samples were also tested by antigencapture ELISA employing biotin-labelled monoclonal antibodies (Wang et al., 2004). The monoclonal antibodies (H5) were a gift from Professor Qin, Institute of Microbiology and Epidemiology, Academy of Military Medical Science. Briefly, 96-well plates (Shenzhen Jinchanhua International) were coated overnight at $4{ }^{\circ} \mathrm{C}$ with purified monoclonal antibodies (3B2B9C5, 3B5C11A10) to AIV $\mathrm{H} 5$ diluted 1000-fold in $50 \mathrm{mM} \mathrm{NaHCO} 3$ buffer ( $\mathrm{pH}$ 9.6). Each well was rinsed and blocked with PBS containing $0.05 \%$ Tween 20 and $3 \%$ BSA. Samples were centrifuged (3000 r.p.m., $5 \mathrm{~min}$ ) and the supernatant was tested. After incubation at $37^{\circ} \mathrm{C}$ for $1 \mathrm{~h}$, the plates were washed five times with PBS/0.5 \% Tween 20. The other monoclonal antibody (3D1D11B2, diluted $1: 3000)$ labelled with biotin was added to the plates. The plates were incubated at $37^{\circ} \mathrm{C}$ for $30 \mathrm{~min}$ and washed five times with PBS/0.5\% Tween 20. Diluted HRP-streptavidin (diluted 1: 1000 in PBS supplemented with $0.5 \%$ Tween 20 and $1.5 \%$ BSA) was added to each well, followed by incubation at $37{ }^{\circ} \mathrm{C}$ for $30 \mathrm{~min}$. The plates were washed five times with PBS/ $0.5 \%$ Tween 20 before the addition of tetramethylbenzidine substrate. The reaction was stopped by the addition of $2 \mathrm{M} \mathrm{H}_{2} \mathrm{SO}_{4}$. The $A_{450 / 630}$ value was measured in triplicate. A blank control, a negative control and a positive control were included on each plate. All reagents were used in a standard volume of $100 \mu$.

Virus isolation. Samples were diluted in PBS containing $2 \mathrm{mg}$ streptomycin $\mathrm{ml}^{-1}, 1000 \mathrm{IU}$ penicillin $\mathrm{ml}^{-1}$ and $20 \mu \mathrm{g}$ amphotericin $\mathrm{B} \mathrm{ml} \mathrm{m}^{-1}$. Nine-day-old embryonated chicken eggs were inoculated with $100 \mu \mathrm{l}$ sample by the chorioallantoic sac route. Five eggs were inoculated per dilution. At 4 days post-inoculation, chorioallantoic fluid was collected and tested by RT-PCR combined with sequencing and by RRT-PCR. RNA extraction was carried out using a QIAamp RNA extraction kit (Qiagen) as described previously. Virus isolation was undertaken in a Biosafety level 3 facility.

\section{RESULTS AND DISCUSSION}

\section{Sensitivity and specificity of the RRT-PCR assay}

Serial dilutions of in vitro-transcribed AIV H5 gene RNA were tested. A wide linear range (from 40 copies per reaction to $4 \times 10^{8}$ copies per reaction of target RNA, $R^{2}=0.997$ ) was detected (Fig. 1). To determine the minimum copy number of $\mathrm{H} 5$ gene RNA that could be detected, each low-concentration dilution was repeated 48 times. Approximately six copies of in vitro-transcribed RNA per reaction could be detected reproducibly ( $95 \%$ confidence lower limits $P=94.5 \%$ ), and sometimes even as few as three copies of target RNA tested positive in our assay (Table 3). In view of the divergence of the $\mathrm{H} 5$ gene, a standard panel containing different clades of influenza virus $\mathrm{A} / \mathrm{H} 5 \mathrm{~N} 1$ was tested. All isolates tested positive. For further evaluation of the sensitivity of the system, $60 \mathrm{H} 5 \mathrm{~N} 1$ isolates originating from different species were tested and all tested positive.

To determine the specificity, throat swabs from 60 patients previously shown to have H1N1 infection were tested and all samples tested negative. To test cross-reactivity with other viruses, nuclear acids (RNA or DNA) extracted from clinical isolates of 14 other viruses (listed in Methods) were evaluated. None of these viruses reacted positively in our assay.
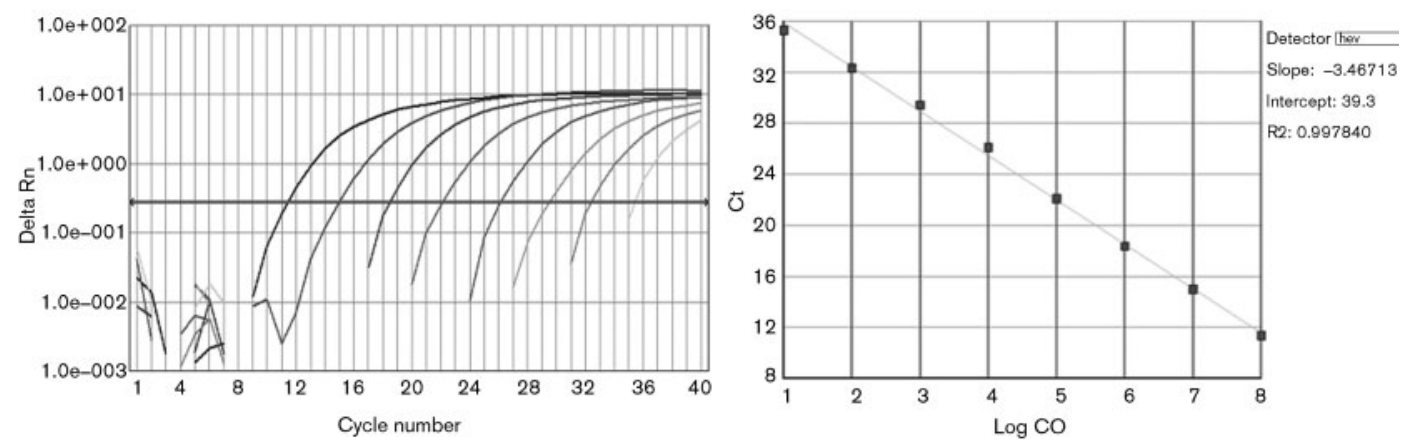

Fig. 1. Sensitivity and dynamic range of RRT-PCR in detection of AIV H5 RNA. Serial dilutions of in vitro-transcribed AIV H5 gene RNA were tested. A wide linear range (from 40 copies to $4 \times 10^{8}$ copies of the control RNA per reaction) was determined in this assay. The intercept of the magnitude of the fluorescence signal (PCR baseline minus curve fit relative fluorescence units) with the horizontal threshold line represents the $\mathrm{Ct}$ value for a given sample. 
Table 3. Detection of different concentrations of in vitro-transcribed AIV H5 gene RNA tested by RRT-PCR

\begin{tabular}{|lrccccc|}
\hline \multirow{2}{*}{ RRT-PCR $^{*}$} & \multicolumn{6}{c|}{ Concentration of in } \\
\cline { 2 - 6 } & $\mathbf{2 . 5}$ & $\mathbf{1 . 2 5}$ & $\mathbf{0 . 6 2 5}$ & $\mathbf{0 . 3 1 3}$ & $\mathbf{0 . 1 5 5}$ & $\mathbf{0 . 0 7 8}$ \\
\hline Positive & 48 & 48 & 47 & 15 & 0 & 0 \\
Negative & 0 & 0 & 1 & 33 & 48 & 48 \\
\hline
\end{tabular}

${ }^{\star}$ Each reaction mix contained $10 \mu \mathrm{l}$ RNA.

\section{Comparison of RRT-PCR with conventional RT- PCR}

The WHO primers are a reliable identification method and are used for $\mathrm{H} 5$ gene detection in many countries as a laboratory test. To compare the sensitivity of RRT-PCR with that of conventional RT-PCR using the WHO primers, throat swabs from 35 birds taken during an HPAIV (H5N1) outbreak and serial dilutions of AIV H5N1 cultures were tested. Thirty-three samples tested positive in our assay, but only 27 samples tested positive by conventional RT-PCR (Table 4). Six of the amplified products that tested positive only in the RRT-PCR were cloned into the pGEM-T Easy vector and sequence identification showed that they were true positive results. The detection limits determined for each test may explain the discordance among the tests, as conventional RT-PCR could only detect $3 \operatorname{EID}_{50}$ whilst our assay detected down to approximately $5 \times 10^{-2} \mathrm{EID}_{50}(\mathrm{Ct}$ value $=37.5)$.

\section{Comparison of RRT-PCR with antigen-capture ELISA}

To compare the sensitivity of RRT-PCR with that of antigen-capture ELISA, the same 35 avian samples and serial dilutions of AIV H5N1 cultures were analysed. Two samples were negative by both assays and 13 samples were positive by both assays; i.e. $42.9 \%$ of the samples were in agreement (Table 4). The 20 samples for which the results differed were positive by RRT-PCR but negative by ELISA; thus ELISA detected $39.4 \%$ of the samples that were positive by RRT-PCR. In tests of serial dilutions of AIV H5N1 cultures, the minimum dilution of AIV H5N1 cultures was approximately $10 \mathrm{EID}_{50}$ for antigen-capture ELISA, showing that it has lower sensitivity than RRT-PCR. This coincides with previously reported data (Ng et al., 2005).

\section{Comparison of RRT-PCR with virus isolation}

The sensitivity of the RRT-PCR assay was compared with that of virus isolation in embryonating eggs from clinical swab samples. One sample was negative by both assays and 18 were positive by both assays (Table 4). The serum sample from the bird whose throat swab was negative in both assays was positive by an HA inhibition assay. Overall, the results of the two assays agreed for 19 samples (54.3\%) and disagreed for 16 samples (45.7\%). Of the 16 samples for which results differed, one sample was positive by virus isolation and negative by RRT-PCR, and 15 samples were positive by RRT-PCR but negative by virus isolation. Thus virus isolation detected $54.5 \%$ of the samples that were positive by RRT-PCR, but $45.5 \%$ (15/33) of the samples that were positive by RRT-PCR were negative by virus isolation. This can partly be explained by the fact that virus isolation detects only live virus; thus virus that may have been inactivated during long-term shipping or storage from Qinghai to Beijing would not be detected, whereas it potentially can be detected by RRT-PCR. On the other hand, one of the 35 samples $(2.9 \%)$ that was negative by RRT-PCR was positive by virus isolation. The cultured material was tested further by RRT-PCR and tested positive. Factors that may adversely affect the sensitivity of the RRT-PCR assay include RT-PCR inhibitory substances in the samples, inefficient RNA extraction procedures and rapid degradation of RNA before testing.

\section{Conclusions}

We have developed a sensitive and specific RRT-PCR assay for the detection of influenza virus A H5 subtype. Compared with conventional RT-PCR, antigen-capture ELISA and virus isolation, RRT-PCR is a more sensitive and convenient method.

Table 4. Comparison of RRT-PCR results with conventional RT-PCR, antigen-capture ELISA and virus isolation results for $\mathrm{H} 5$ subtype influenza virus

\begin{tabular}{|c|c|c|c|c|c|c|}
\hline \multirow[t]{2}{*}{ RRT-PCR } & \multicolumn{2}{|c|}{ Conventional RT-PCR } & \multicolumn{2}{|c|}{ Antigen-capture ELISA } & \multicolumn{2}{|c|}{ Virus isolation } \\
\hline & Positive & Negative & Positive & Negative & Positive & Negative \\
\hline Positive & 27 & 6 & 13 & 20 & 18 & 15 \\
\hline Negative & 0 & 2 & 0 & 2 & 1 & 1 \\
\hline
\end{tabular}




\section{ACKNOWLEDGEMENTS}

We thank the HPAI pathogens study team for virus culture and titre determination in this work. This study was supported by grants from the National High Technology Research and Development Program of China (863 Program) from the Ministry of Science and Technology, People's Republic of China.

\section{REFERENCES}

CDC (1997). Isolation of avian influenza A (H5N1) viruses from humans - Hong Kong, May-December 1997. MMWR Morb Mortal Wkly Rep 46, 1204-1207.

CDC (2004). Cases of influenza A (H5N1) - Thailand, 2004. MMWR Morb Mortal Wkly Rep 53, 100-103.

Chen, W., Xu, Z., Mu, J., He, B., Yang, L., Lin, L., Meng, S., Mu, F., Gan, H. $\&$ other authors (2004). Real-time quantitative fluorescent reverse transcriptase-PCR for detection of severe acute respiratory syndromeassociated coronavirus RNA. Mol Diagn 8, 231-235.

FAO (2005). Economic and social impacts of avian influenza. http:// www.fao.org/AG/AGAINFO/subjects/en/health/diseases-cards/cd/ documents/Economic-and-social-impacts-of-avian-influenza-Geneva. pdf

Holland, P. M., Abramson, R. D., Watson, R. \& Gelfand, D. H. (1991). Detection of specific polymerase chain reaction product by utilizing the $5^{\prime}$ to $3^{\prime}$ exonuclease activity of Thermus aquaticus DNA polymerase. Proc Natl Acad Sci U S A 88, 7276-7280.

Kubar, A., Saygun, I., Ozdemir, A., Yapar, M. \& Slots, J. (2005). Realtime polymerase chain reaction quantification of human cytomegalovirus and Epstein-Barr virus in periodontal pockets and the adjacent gingiva of periodontitis lesions. J Periodontal Res 40, 97-104.

Kuypers, J., Wright, N., Ferrenberg, J., Huang, M. L., Cent, A., Corey, L \& Morrow, R. (2006). Comparison of real-time PCR assays with fluorescent-antibody assays for diagnosis of respiratory virus infections in children. J Clin Microbiol 44, 2382-2388.

Lee, M. S., Chang, P. C., Shien, J. H., Cheng, M. C. \& Shieh, H. K. (2001). Identification and subtyping of avian influenza viruses by reverse transcription-PCR. J Virol Methods 97, 13-22.

Liu, J., Xiao, H., Lei, F., Zhu, Q., Qin, K., Zhang, X. W., Zhang, X. L., Zhao, D., Wang, G. \& other authors (2005). Highly pathogenic H5N1 influenza virus infection in migratory birds. Science 309, 1206.

Livak, K. J., Flood, S. J., Marmaro, J., Giusti, W. \& Deetz, K. (1995). Oligonucleotides with fluorescent dyes at opposite ends provide a quenched probe system for detecting PCR product and nucleic acid hybridization. PCR Methods Appl 4, 357-362.

Munch, M., Nielsen, L. P., Handberg, K. J. \& Jorgensen, P. H. (2001). Detection and subtyping (H5 and H7) of avian type A influenza virus by reverse transcription-PCR and PCR-ELISA. Arch Virol 146, 87-97.

Ng, E. K. O., Cheng, P. K. C., Ng, A. Y. Y., Hoang, T. L. \& Lim, W. W. L. (2005). Influenza A H5N1 detection. Emerg Infect Dis 11, 1303-1305.

Palmer, S., Wiegand, A. P., Maldarelli, F., Bazmi, H., Mican, J. M., Polis, M., Dewar, R. L., Planta, A., Liu, S. \& other authors (2003). New real-time reverse transcriptase-initiated PCR assay with single-copy sensitivity for human immunodeficiency virus type 1 RNA in plasma. J Clin Microbiol 41, 4531-4536.

Perkins, S. M., Webb, D. L., Torrance, S. A., El Saleeby, C., Harrison, L. M., Aitken, J. A., Patel, A. \& DeVincenzo, J. P. (2005). Comparison of a real-time reverse transcriptase PCR assay and a culture technique for quantitative assessment of viral load in children naturally infected with respiratory syncytial virus. J Clin Microbiol 43, 2356-2362.

Starick, E., Romer-Oberdorfer, A. \& Werner, O. (2000). Type- and subtype-specific RT-PCR assays for avian influenza A viruses (AIV). $J$ Vet Med B Infect Dis Vet Public Health 47, 295-301.

Tran, T. H., Nguyen, T. L., Nguyen, T. D., Luong, T. S., Pham, P. M., Nguyen, V. C., Pham, T. S., Vo, C. D., Le, T. Q. \& other authors (2004). Avian influenza A (H5N1) in 10 patients in Vietnam. $N$ Engl J Med 350, 1179-1188.

Viseshakul, N., Thanawongnuwech, R., Amonsin, A., Suradhat, S., Payungporn, S., Keawchareon, J., Oraveerakul, K., Wongyanin, P., Plitkul, S. \& other authors (2004). The genome sequence analysis of $\mathrm{H} 5 \mathrm{~N} 1$ avian influenza A virus isolated from the outbreak among poultry populations in Thailand. Virology 328, 169-176.

Wang, C., Tian, X., Cao, Z., Yu, X., Sun, M., Chen, X., Wang, H. \& Tian, K. (2004). Establishment of H5 avian influenza virus capture ELISA employing biotin labeled monoclonal antibody. Acta Lab Anim Sci Sin 12, 204-207.

WHO (2005). Recommended laboratory tests to identify avian influenza A virus in specimens from humans. http://www.who.int/ csr/disease/avian_influenza/guidelines/avian_labtests2.pdf

WHO (2006). Cumulative number of confirmed human cases of avian influenza $\mathrm{A} /(\mathrm{H} 5 \mathrm{~N} 1)$ reported to WHO. http://www.who.int/csr/ disease/avian_influenza/country/cases_table_2006_05_23/en/ index.html

Wright, K. E., Wilson, G. A. R., Novosad, D., Dimock, C., Tan, D. \& Weber, J. M. (1995). Typing and subtyping of influenza viruses in clinical samples by PCR. J Clin Microbiol 33, 1180-1184. 